\title{
$\begin{array}{ll}\text { Research Square } & \text { Preprints are preliminary reports that have not undergone peer review. } \\ \text { They should not be considered conclusive, used to inform clinical practice, }\end{array}$
}

\section{Lichen communities as a multiscale correlative indicator of elevational and land use-land cover gradients in the Himalayas}

Himanshu Rai ( $\square$ himanshurai08@yahoo.com )

Banaras Hindu University Department of Botany https://orcid.org/0000-0001-8070-0602

Roshni Khare

Savitribai Phule Pune University

Deepak Upadhyay

GB Pant Institute of Himalayan Environment and Development: Govind Ballabh Pant National Institute of Himalayan Environment and Sustainable Development

Rajan Kumar Gupta

Banaras Hindu University Department of Botany

Avinash B. Ade

Savitribai Phule Pune University

Sarnam Singh

IIRS: Indian Institute of Remote Sensing

Dalip Kumar Upreti

CSIR-National Botanical Research Institute

\section{Research Article}

Keywords: Himalaya, Land use- land cover, Lichens, Ordination, SRTM-DEM

Posted Date: November 23rd, 2021

DOI: https://doi.org/10.21203/rs.3.rs-1100727/v1

License: (a) (i) This work is licensed under a Creative Commons Attribution 4.0 International License. Read Full License 


\section{Abstract}

Elevation and land use/ land cover (LULC) plays an important role in the diversity of lichens in the Himalayas. The elevation gradients and LULC can be remotely assessed using remote sensing (RS) and geographical information systems (GIS). The current study was done in the Chopta-Tungnath landscape in the Kedarnath wildlife sanctuary, western Himalaya, India. Digital elevation modelling of the study area was done using shuttle radar topography mission data (SRTM-DEM) processed in Esri ArcGIS ${ }^{\circledR}$ ArcMAPTM 10.5 , to assess the elevation gradient of the study area and selection of four lichen sampling sites. The LULC maps of the study area were prepared using Landsat 8 and Google Earth Pro 7.3.2.5776 imagery processed using Leica ${ }^{\text {TM }}$ ERDAS IMAGINE ${ }^{\circledR}$ 9.2. An elevation gradient of $2750 \mathrm{~m}$ to $3703 \mathrm{~m}$ was recorded by SRTM-DEM. The LULC analysis resulted in five LULC classes of which the four sampling sites fall in the 3 LULC classes. The principal component analysis (PCA), used to analyse the lichen communities along the RS-GIS recognized LULC classes. The study found lichen communities to be a proxy to the LULC classes in the Himalayas with clear gradients of growth forms and habitat subsets along the increasing elevation gradient.

\section{Introduction}

Studies on Lichens for the last few decades have been found them to be good indicators of land use in both managed as well as natural habitats reflecting the effects of both anthropogenic (i.e., habitat perturbations and pollution) and natural factors (i.e., invasive species, competition, and land-use intensity) (Pinho et al. 2012; Boch et al. 2016; Chuquimarca et al. 2019). Though there have been studies where remote sensing (RS) and geographical information systems (GIS) have been successfully used in assessing land use land cover (LULC) concerning dominant vegetation, their use for lichen diversity studies is still lacking (Prasad et al. 2015).

Among the various RS-GIS studies, Google Earth and Landsat data have been extensively used for LULC studies (Uddin et al. 2015; Debnath et al. 2017; Sharma et al. 2018; Mondal et al. 2019). The Google Earth imagery, an open-source data freely available has been instrumental for visual supervised classification of Landsat data and have been found efficient in the overall remote sensing classification of LULC (Tilahun and Teferie 2015; Uddin et al. 2015; Debnath et al. 2017; Sharma et al. 2018; Mondal et al. 2019).

In the present study, we have attempted digital elevational modelling of shuttle radar topography mission data in site selection and defining the elevation gradient of the Chopta-Tungnath landscape. The LULC estimation was done using Landsat-8 and Google earth data and their comparative efficiency was assessed. The above-mentioned RS-GIS analysis was correlated with the change in lichen diversity along with elevation and LULC changes to examine the capability of lichen communities as indicators of RS-GIS defined LULC in the mountainous terrain of Chopta-Tungnath landscape situated in the southern extreme of the Kedarnath wildlife sanctuary, western Himalaya.

\section{Materials And Methods}

\subsection{Study area:}

The study was conducted in the temperate-alpine habitats of Chopta-Tungnath (between $30^{\circ} 28^{\prime} 39^{\prime \prime}-30^{\circ} 29^{\prime} 51^{\prime \prime} \mathrm{N}$ latitude and $79^{\circ} 12^{\prime} 9^{\prime \prime}$ to $79^{\circ} 13^{\prime} 21^{\prime \prime} \mathrm{E}$ longitude), a pasture and a trekking-pilgrimage area situated on the south-western fringe of Kedarnath wildlife sanctuary in the Garhwal Himalayas of Rudraprayag district, Uttarakhand (Figure 1A). The climate of the landscape is characterized by severe frost, diurnal to seasonal blizzards, hailstorms, and daily orographic precipitation at higher altitudes, throughout the year (Khare et al. 2010). The precipitation ensues in the form of snow, sleet-hail, rains, and showers throughout the year (Rai et al. 2012). The snowfall occurs from November to April. Snow melting in April is the major source of soil water before the monsoon. Maximum rainfall is recorded in July-August (Figure 1B). The mean monthly atmospheric temperature ranges from a maximum of $19^{\circ}-37^{\circ} \mathrm{C}$ (May to October) to a minimum, as low as $-15^{\circ} \mathrm{C}$ (December to February) (Figure 1B).

The area is known for the shrine of Tungnath, situated at the Tungnath ridge a major relief structure dividing the drainage of the region. The shrine is associated with alpine grassland (the Tungnath Bugyal). The Tungnath shrine lies $2 \mathrm{~km}$ below the Chandrashila Peak, the highest point of the landscape. The landscape is characterized by rocky outcrops having moderate to steep slopes. The topography of the area is dominated by ridges formed by exposed rocks and patches of flat temperate and alpine grasslands. The soil in the area is thin-layered, coarse-textured/ sandy loam at lower altitudes and sandy at higher altitudes, with proper drainage and acidic $\mathrm{pH}(\mathrm{pH} 3.0-5.5)$ (Rai et al. 2012). The vascular plant vegetation of the study area shows stratified composition along the elevation gradient consisting of temperate mixed oak and coniferous forest at lower elevations, transitioning into the subalpine forest and ultimately culminating into alpine scrub/ grassland (Rai et al. 2012). 


\subsection{Remote sensing (RS) and geographical information systems (GIS) analysis:}

\subsubsection{Topographic studies using shuttle radar topography mission-digital elevation model (SRTM-DEM) data:}

The topographic study of the Chopta-Tungnath landscape was done on shuttle radar topography mission-digital elevation model (SRTMDEM) data. The SRTM was an international effort consisting of an 11-day mission of space shuttle Endeavour in February 2000, which mapped almost the entire earth from $56^{\circ} \mathrm{S}$ to $60^{\circ} \mathrm{N}$ with STRM payload employing interferometric synthetic-aperture radar technique and obtained a high-resolution digital topographical data of earth (Nikolakopoulos et al. 2006). SRTM-DEM data covers compiled by Consultative Group for International Agriculture Research Consortium for Spatial Information (CGIAR-CSI) covers about $80 \%$ of the globe. The SRTM $90 \mathrm{~m}$ DEMs are with a resolution of $90 \mathrm{~m}$ and are available for free download as $5 \times 5$-degree tiles at http://srtm.csi.cgiar.org/.

The 5×5-degree tile, SRTM, version 4, $90 \mathrm{~m}$ data of the study area was downloaded as Geo TIFF file from http://srtm.csi.cgiar.org/srtmdata/ (Fig.2). The data file was pre-processed for noise reduction, identification, and elimination of manmade terrain features (if any), and for estimating and eliminating the forest canopy data (Köthe et al. 2009). The SRTM Geo TIFF file was processed in Esri ArcGIS ${ }^{\circledR}$ ArcMAP $^{\text {TM }}$ 10.5. The study area was clipped from the regional downloaded SRTM Geo TIFF file, using the shapefile created from Google Earth Pro 7.3.2.5776 (GEPr). The processed SRTM data along with prior knowledge of the authors was used for the selection of probable sample areas. The final georeferenced and geotagged elevation map of the study area with sampling sites and landmarks was prepared using cumulative input data from SRTM-DEM, GEPr, and previous field studies (Fig.2).

\subsubsection{Land use land cover (LULC) classification:}

The collative use of google earth imagery and Landsat data was done to assess and prepare the land use/ land cover of the study area (Fig. 4). The Google earth land use/land cover map was prepared by visual interpretation of data based on size, shape, tone, texture, association, and relationship to other objects (Fig. 4).

To study the Landsat-based land use/ land cover (LULC) of the study area, the Landsat 8 satellite data (path 145, row-39) of 18 February 2014 and $10^{\text {th }}$ June 2014 was downloaded from the Earth Explorer website (https://earthexplorer.usgs.gov/ ). The satellite data was imported, stacked and the subset of area of interest (AOI) was created using Leica ${ }^{\text {TM }}$ ERDAS IMAGINE $^{\circledR}$ 9.2. The image was processed for preparing the unsupervised false-colour composite (FCC) map of the AOI using three bands $(5,4$ and, 3$)$, which was used in the field excursions for ground-truthing. For Google earth (GE) LULC studies the GE imagery of the Chopta-Tungnath landscape was downloaded using Google Earth Pro 7.3.2.5776 (GEPr). The images were imported, stacked, noise reduction, image enhancement, and georeferencing were done as pre-processing (Fig. 3). The GEPr imagery was processed for the preparation of the LULC map of AOI using 8 classification classes in Leica ${ }^{\text {TM }}$ ERDAS IMAGINE ${ }^{\circledR}$ 9.2. The preliminary LULC maps i.e., FCC image by Landsat 8 and GEPr LULC class maps were finally interpreted by supervised classification based on ground-truthing (Fig. 3).

Reconnaissance field visits/surveys were carried out in different months during 2014-2018 to establish the relationship between land use/ land cover and their tonal variation on the satellite data (Fig. 4). Ground truthing of the Landsat 8 FCC maps/ GEPr LULC class maps was done using handheld GPS (Garmin GPSMAP ${ }^{\circledR} 76$ S).

The final land use/land cover (LULC) was interpreted using digital and visual analysis of Landsat 8 satellite/ GEPr-LULC data. Supervised classification was performed with the training sites of known targets and then the spectral signatures of these sites were extrapolated to other unknown classes (Fig. 3). For this, the Gaussian maximum likelihood classification (GMLC) algorithm was used. The classifier used the training statistics to compute a probability value of whether it belongs to a particular class, which allows for the within-class spectral variance. In this image, the analyst used prior knowledge to weigh the probability function. GMLC provided the highest classification accuracies (Lillesand et al. 2015). For visual analysis elements of visual interpretation like tone, texture, shadow, was used to classify the land cover of the study area using Google Earth imagery and ground-truthing observations during field visits (Fig. 3). The LULC class area of each land use was calculated in $\mathrm{km}^{2}$ and percent. The comparative error matrix and accuracy of visual (Google Earth Pro) and digital (Landsat 8, 2014) interpretation for the LULC classes were assessed using kappa index statistics and area measurements.

\subsection{The quantitative study of lichen diversity:}

\subsubsection{Field methods, collection curation, and identification of lichens:}

Based on the SRTM-DEM and previous field visit experiences of the two authors (i.e., Himanshu Rai and Roshni Khare), four sites of the collection were selected along the bridle approach path following the increasing elevation gradient from Chopta to Chandrashila through 
Tungnath (Fig 4. Table 1). A circular plot of $24 \mathrm{~m}$ diam. was randomly selected at each site along the study landscape (Gasparyan et al. 2018; Nag et al. 2019). The lichen diversity was recorded employing a standardized probabilistic method with three $10 \times 50 \mathrm{~cm}$ narrow frequency grids which were subdivided into five sampling units of $10 \times 10 \mathrm{~cm}$, laid randomly i.e., fifteen, $10 \times 10 \mathrm{~cm}$ sampling units were laid in each plot (Asta et al. 2002; Scheidegger et al. 2002; Rai et al. 2012a, b; Nag et al. 2019). The lichen samples collected were airdried and curated according to the standardized protocol (Obermayer 2002; Rai et al. 2014b).

The collected lichens were identified up to the species level at the Lichenology laboratory and herbarium (LWG) of the National Botanical Research Institute (NBRI), Lucknow, Uttar Pradesh, India using standardized morpho-anatomical examination, chemical spot tests, standardized thin-layer chromatography, and relevant literature (Awasthi 2007; Orange et al. 2010; Elix 2014; Rai et al. 2014b). The authenticated lichen samples were deposited as voucher specimens in the herbarium (LWG), NBRI.

\subsection{Data analysis:}

The lichen assemblage of all the four collection sites was quantitatively analyzed for frequency, regarding species richness (number of species) and growth form diversity, (Curtis and McIntosh 1950; Rai et al. 2012). The indirect gradient ordination method, principal component analysis (PCA), was used to summarise the compositional differences of lichen communities between the sites using the varcovariance matrix, employing singular value decomposition, along the RS-GIS recognized LULC classes (Gauch 1982; Ter Braak 1995; Ter Braak and Prentice 2004; Rai et al. 2012).

\section{Results}

\subsection{Remote sensing (RS) and geographical information systems (GIS) analysis:}

The SRTM-DEM obtained with a pixel size of $90 \mathrm{~m}$ covered a total area of $10.25 \mathrm{~km}^{2}$ with elevational variation ranging from $2750 \mathrm{~m}$ to 3703m (Fig. 5). The collative LULC studies using Landsat 8, FCC, and Google Earth imagery identified five LULC classes (Table 2, Fig 6). Among the identified LULC classes the mixed conifer forest dominated followed by temperate grassland, Rhododendron sub-alpine forests, alpine grassland, and snow (Table 2). The accuracy assessment found the LULC classes derived by the visual interpretation using Google Earth Pro imagery to be more efficient than the LULC classes derived by the digital classification using Landsat 8, 2014 data (Table 3). The reconnaissance field visits/ surveys carried out during the study period (i.e., 2014-2018) further observed stratification of vegetation along increasing elevational gradients in the landscape. The LULC classes identified through RS-GIS studies were defined by these vegetational stratifications. The mixed conifer forests were dominated by strands of Quercus semecarpifolia and Rhododendron arboreum with few patches of Abies pindrow and Taxus baccata trees (Fig. 7). The temperate grasslands developed in the open canopy area in the coniferous forests (Fig. 7). The Rhododendron sub-alpine forests entirely consisted of coppices of Rhododendron campanulatum (Fig. 7). The alpine grassland was dominated by the vegetation of herb species of Anemone, Potentilla, Aster, Geranium, Meconopsis, Primula, and Polemonium, with scattered patches of shrubs of Rhododendron anthopogon and Juniperus species (Fig. 7).

\subsection{Average lichen community structure, patterns.}

The lichen assemblage recorded from the four sites in the Chopta-Tungnath landscape consisted of 104 species belonging to 28 genera, 11 families, and four growth forms (Table 4). Among the lichen families, Parmaliaceae (37 species) dominated followed by Physciaceae (14 species), Cladoniaceae (12 species), Stereocaulaceae (8 species), Collamatceae, Peltigeraceae, and Ramalinaceae (6 species each), Umbilicariaceae (2 species), and Nephromataceae (1 species) (Table 4). Among the various growth forms of lichen recorded leafy foliose (65 species) dominated followed by compound (18 species)-having squamules as primary thallus bearing erect fruticose body as the secondary thallus, fruticose (14 species), and powdery leprose (3 species) (Table 4). The number of lichen species recorded was maximum in site 1 (i.e., 50 species) followed by site 2 ( 19 species), site 3 (14 species), and site 4 (12 species). The lichen habitat-subsets show a striking gradient where the bark inhabiting corticolous lichen species dominated in sites 1 and 2 gradually replaced by more dominant soil-inhabiting terricolous lichen species in sites 3 and 4 (Fig. 8A). Among the growth forms, the foliose lichens were present throughout the landscape, the more complex compound growth forms increased along with increasing elevation gradients (Fig. 8B)

\subsection{Lichen communities and RS-GIS defined LULC classes:}

The PCA analysis required 3 components (axis) to account for a 100\% variation in the data set. The first two axes of PCA explained $87.2 \%$ of the variance, and each axis explained 69.6 and $16.6 \%$ of the variance, respectively (Fig.9). Sites 1 and 2 mapped separately whereas sites 3 and 4 mapped coherently due to their inherent similarity and differences in the diversity of constituent lichen species at 
each site (Fig. 9). The PCA biplot further concluded that the lichen community at site 1 was indicative of the RS-GIS recognized LULC class mixed conifer forest, whereas site 2 of Rhododendron sub-alpine forest and sites 3 and 4 of alpine grassland (Fig. 9).

\section{Discussion}

The Himalayan vegetation is highly influenced by climatic, elevational, geological, topographical, and anthropogenic parameters (Singh and Singh 1987). Lichens are among some of the organisms which exhibit substantial distribution throughout the Himalayan landscapes with diverse growth forms inhabiting all the terrestrial domains (Upreti 1987). The LULC types recognized using Landsat-8 and Google earth imagery gives a more distinguished forest cover estimation than already known of the area (Rai et al. 2012, 2014). The presence of temperate grasslands in the open canopy regions of the mixed coniferous forests is more prominent in the LULC maps prepared by the RS-GIS data (Rai et al. 2012, 2014). The change in both quantitative (i.e., the number of species, quadrat frequency of the lichen species) and qualitative (growth forms, habitat subsets) diversity along the LULC and the elevational gradient is per previous studies done on terricolous lichen communities (Rai et al. 2012, 2014). The higher species diversity in low elevation-mixed conifer forests is due to the presence of tree barks of the phorophytes (Quercus spp., Rhododendron spp., Abies spp. and Taxus spp.) as preferred substratum, which fades out at higher elevation where the tree line diminishes and is replaced by alpine grasslands having soil/ ground and rocks the only substratum available for the lichens to colonize (Negi 2000; Rai et al. 2012, 2014). The PCA analysis establishes that the lichen communities are indicative of RS-GIS-recognized LULC classes, which harbour different combinations of lichen growth forms and habitat subsets guided by the LULC classes. The overall efficient recognition of LULC classes by Google earth imagery over Landsat8 data is because the GEPr program prepares maps by superimposing satellite images, aerial photography, and GIS data making the output maps more accurate.

\section{Conclusion}

The study hereby elucidates the influence of LULC on the lichen communities along the elevation gradient of the Chopta-Tungnath landscape. The efficiency of GEPr-LULC mapping over Landsat 8-FCC indicates their superior remote sensing LULC analytic applications. The clustering of lichen communities to specific LULC with defined combinations of growth forms and habitat subsets, concludes their ability and probable applications as indicators of different vegetational covers and land use in the Himalaya. The findings can be used for developing forest management policies and can be of considerable help for biodiversity assessment in the Himalayas.

\section{Declarations}

Acknowledgments Authors are grateful to the Director, CSIR-National Botanical Research Institute, Lucknow for providing necessary laboratory facilities. The work of Himanshu Rai was supported by the Uttarakhand State Council for Science and Technology, through the MRD project grant (UCOST-UCS\&T/R\&D/LS-26/11-12/4370 dated 17-03-2012).

\section{References}

1. Asta J, Erhardt W, Ferretti M, Fornasier F, Kirschbaum U, Nimis PL, Purvis OW, Pirintsos S, Scheidegger C, Van Haluwyn C, Wirth V (2002) Mapping Lichen Diversity as an Indicator of Environmental Quality.. In: In: Nimis PL, Scheidegger C, Wolseley PA (eds) Monitoring with Lichens - Monitoring Lichens. Springer, Dordrecht, pp 273-279. https://doi.org/10.1007/978-94-010-0423-7_19

2. Awasthi DD (2007) A compendium of the macrolichens from India, Nepal, and Sri Lanka. Bishen Singh Mahendra Pal Singh, Dehra Dun

3. Boch S, Prati D, Schöning I, Fischer M (2016) Lichen species richness is highest in non-intensively used grasslands promoting suitable microhabitats and low vascular plant competition. Biodivers Conserv 25:225-238. https://doi.org/10.1007/s10531-0151037-y

4. Chuquimarca L, Gaona FP, Iñiguez-Armijos C, Benítez Á (2019) Lichen Responses to Disturbance: Clues for Biomonitoring Land-use Effects on Riparian Andean Ecosystems. Diversity 11:73. https://doi.org/10.3390/d11050073

5. Curtis JT, Mclntosh RP (1950) The Interrelations of Certain Analytic and Synthetic Phytosociological Characters. Ecology 31:434455. https://doi.org/10.2307/1931497

6. Debnath J, Das N, Ahmed I, Bhowmik M (2017) Channel migration and its impact on land use/land cover using RS and GIS: A study on Khowai River of Tripura, North-East India. The Egyptian Journal of Remote Sensing and Space Science 20:197-210.

https://doi.org/10.1016/j.ejrs.2017.01.009

Page 5/18 
7. Elix JA (2014) A catalogue of standardized thin layer chromatographic data and biosynthetic relationships for lichen substances, 3rd edn. Australian National University, Canberra, Australia. https://www.anbg.gov.au/abrs/lichenlist/Chem\%20Cat\%203.pdf Accessed on 15 Nov 2019.

8. Gasparyan A, Sipman HJM, Marini L, Nascimbene J (2018) The inclusion of overlooked lichen microhabitats in standardized forest biodiversity monitoring. The Lichenologist 50:231-237. http://dx.doi.org/10.1017/S0024282918000087

9. Gauch HG (1982) Multivariate Analysis in Community Ecology. Cambridge University Press, Cambridge. https://doi.org/10.1017/СBO9780511623332

10. Khare R, Rai H, Upreti DK, Gupta RK, Plants, Pollution E, Lucknow CSIR-NBRI (2010) U.P, 8-11 Dec, pp.135-136. http://dx.doi.org/10.13140/2.1.1812.5604

11. Köthe R, Bock M (2009) Preprocessing of digital elevation models-derived from laser scanning and radar interferometry-for terrain analysis in geosciences. Proceedings of geomorphometry, Zurich, Switzerland, 31

12. Mondal T, Basu P, Qureshi Q, Jhala Y (2019) An assessment of land use land cover change in Central Highland of Deccan Peninsula and Semi-Arid tracts of India. bioRxiv, 665794. https://doi.org/10.1101/665794

13. Nag P, Gupta RK, Upreti DK (2019) Lichenized fungi Stereocaulon foliolosum Nyl. (Stereocaulaceae, Ascomycota), indicator of ambient air metal deposition in a temperate habitat of Kumaun, central Himalaya, India. Tropical Plant Research 6:199-205. https://doi.org/10.22271/tpr.2019.v6.i2.029

14. Negi HR (2000) On the patterns of abundance and diversity of macrolichens of Chopta-Tunganath in the Garhwal Himalaya. J Biosci 25:367-378. doi: http://dx.doi.org/10.1007/BF02703790

15. Nikolakopoulos KG, Kamaratakis EK, Chrysoulakis N (2006) SRTM vs ASTER elevation products. Comparison for two regions in Crete, Greece. Int J Remote Sens 27:4819-4838. http://dx.doi.org/10.1080/01431160600835853

16. Obermayer W (2002) Management of a Lichen Herbarium.. In: In: Kranner IC, Beckett RP, Varma AK (eds) Protocols in Lichenology: Culturing, Biochemistry, Ecophysiology and Use in Biomonitoring. Springer, Berlin Heidelberg, pp 507-523. https://doi.org/10.1007/978-3-642-56359-1_29

17. Orange A, James PW, White FJ (2001) Microchemical methods for the identification of lichens. British Lichen Society, London

18. Pinho P, Bergamini A, Carvalho P, Branquinho C, Stofer S, Scheidegger C, Máguas C (2012) Lichen functional groups as ecological indicators of the effects of land-use in Mediterranean ecosystems. Ecol Ind 15:36-42. https://doi.org/10.1016/j.ecolind.2011.09.022

19. Prasad N, Semwal M, Roy PS (2015) Remote Sensing and GIS for Biodiversity Conservation.. In: In: Upreti DK, Divakar PK, Shukla V, Bajpai R (eds) Recent Advances in Lichenology: Modern Methods and Approaches in Biomonitoring and Bioprospection, vol 1. Springer India, New Delhi, pp 151-179. https://doi.org/10.1007/978-81-322-2181-4_7

20. Rai H, Gupta RK, Upreti DK, Nag P (2014) Distribution Pattern of Terricolous Lichens in Garhwal Himalayas (Chopta-Tungnath Tract) with Reference to Morphological and Environmental Variables. In: Gupta RK, Kumar M (eds) Diversity of Lower Plants, I.K. International Publisher, New Delhi, India, pp 264-278. http://dx.doi.org/10.13140/2.1.3237.9689

21. Rai H, Khare R, Gupta RK, Upreti DK (2012a) Terricolous lichens as indicator of anthropogenic disturbances in a high altitude grassland in Garhwal (Western Himalaya), India. Botanica Orientalis 8:16-23. https://doi.org/10.3126/botor.v8i0.5554

22. Rai H, Khare R, Upreti DK, Ahti T (2014a) Terricolous Lichens of India: Taxonomic Keys and Description.. In: In: Rai H, Upreti DK (eds) Terricolous Lichens in India: Volume 2: Morphotaxonomic Studies. Springer New York, New York, NY, pp 17-294. https://doi.org/10.1007/978-1-4939-0360-3_2

23. Rai H, Khare R, Upreti DK, Nayaka S (2014b) Terricolous Lichens of India: An Introduction to Field Collection and Taxonomic Investigations. In: Rai H, Upreti DK (eds) Terricolous Lichens in India: Volume 2: Morphotaxonomic Studies. Springer New York, pp 116. https://doi.org/10.1007/978-1-4939-0360-3_1

24. Rai H, Upreti DK, Gupta RK (2012b) Diversity and distribution of terricolous lichens as indicator of habitat heterogeneity and grazing induced trampling in a temperate-alpine shrub and meadow. Biodivers Conserv 21:97-113. http://dx.doi.org/10.1007/s10531-0110168-z

25. Scheidegger C, Groner U, Keller C, Stofer S (2002) Biodiversity Assessment Tools - Lichens.. In: In: Nimis PL, Scheidegger C, Wolseley PA (eds) Monitoring with Lichens-Monitoring Lichens. Springer, Netherlands, pp 359-365. https://doi.org/10.1007/978-94010-0423-7_35

26. Sharma J, Prasad R, Mishra VN, Yadav VP, Bala R (2018) Land Use and Land Cover Classification of Multispectral LANDSAT-8 Satellite Imagery Using Discrete Wavelet Transform. International Archives of the Photogrammetry, Remote Sensing and Spatial Information Sciences 42:5. https://doi.org/10.5194/isprs-archives-XLII-5-703-2018

Page 6/18 
27. Singh JS, Singh SP (1987) Forest vegetation of the Himalaya. The Botanical Review 53:80-192.

https://doi.org/10.1007/BF02858183

28. Ter Braak CJF (1995) Ordination.. In: In: Ter Braak CJF, Van Tongeren OFR, Jongman RHG (eds) Data Analysis in Community and Landscape Ecology. Cambridge University Press, Cambridge, pp 91-173. https://doi.org/10.1017/CB09780511525575.007

29. Ter Braak CJF, Prentice IC (2004) A Theory of Gradient Analysis. Adv Ecol Res 34:235-282. https://doi.org/10.1016/S00652504(03)34003-6

30. Tilahun A, Teferie B (2015) Accuracy assessment of land use land cover classification using Google Earth. American Journal of Environmental Protection 4:193-198. https://doi.org/10.11648/j.ajep.20150404.14

31. Uddin K, Chaudhary S, Chettri N, Kotru R, Murthy M, Chaudhary RP, Ning W, Shrestha SM, Gautam SK (2015) The changing land cover and fragmenting forest on the Roof of the World: A case study in Nepal's Kailash Sacred Landscape. Landscape and Urban Planning 141:1-10. https://doi.org/10.1016/j.landurbplan.2015.04.003

32. Upreti DK (1998) Diversity of lichens in India.. In: In: Agarwal SK, Kaushik JP, Kaul KK, Jain AK (eds) Perspectives in environment. APH Publishing Corporation, New Delhi, pp 71-79

\section{Tables}

Table 1: Geo-attributes, of the four collection sites and prominent landmarks of Chopta-Tungnath, Kedarnath wildlife sanctuary, western Himalaya

\begin{tabular}{|c|c|c|}
\hline Landmarks / collection sites & Coordinates & Average elevation (m) \\
\hline Chopta chatti & N $30^{0} 29^{\prime} 05.8^{\prime \prime}$ E $79^{0} 11^{\prime} 59.7^{\prime \prime}$ & 2838 \\
\hline Site 1 & N $30^{0} 29^{\prime} 12.03^{\prime \prime}$ E $79^{0} 12^{\prime} 05.3^{\prime \prime}$ & 2990 \\
\hline Site 2 & N $30^{0} 29^{\prime} 18.3^{\prime \prime}$ E $79^{0} 12^{\prime} 31.3^{\prime \prime}$ & 3236 \\
\hline Site 3 & N $30^{0} 29^{\prime} 18.2^{\prime \prime}$ E $79^{0} 12^{\prime} 60.0^{\prime \prime}$ & 3442 \\
\hline Site 4 & N $30^{0} 29^{\prime} 12.7^{\prime \prime}$ E $79^{0} 13^{\prime} 16.4^{\prime \prime}$ & 3668 \\
\hline Tungnath temple complex & N $30^{0} 29^{\prime} 17.8^{\prime \prime}$ E $79^{0} 13^{\prime} 01.1^{\prime \prime}$ & 3640 \\
\hline Chandrashila & N $30^{0} 29^{\prime} 13.1^{\prime \prime}$ E $79^{0} 13^{\prime} 18.2^{\prime \prime}$ & 3672 \\
\hline
\end{tabular}

Table 2: The land use land cover (LULC) area of the visual (Google Earth Pro) and digital-supervised (Landsat 8, 2014) classification of the study landscape (Chopta-Tungnath)

\begin{tabular}{llllll}
\hline SNo. & LULC classes & $\begin{array}{l}\text { Visual classification area } \\
\left(\mathbf{k m}^{2}\right)\end{array}$ & $\begin{array}{l}\text { Area } \\
(\%)\end{array}$ & $\begin{array}{l}\text { Digital-supervised classification } \\
\text { area }\left(\mathbf{k m}^{2}\right)\end{array}$ & $\begin{array}{l}\text { Area } \\
(\%)\end{array}$ \\
\hline 1. & Mixed conifer forest & 5.31 & 51.81 & 4.90 & 47.80 \\
2. & Temperate grassland & 2.44 & 23.80 & 3.40 & 33.17 \\
3. & $\quad \begin{array}{l}\text { Rhododendron sub-alpine } \\
\text { forest }\end{array}$ & 0.14 & 1.37 & 0.25 & 2.44 \\
$4 . \quad$ & Alpine grassland & 2.17 & 21.17 & 1.55 & 15.12 \\
5. & Snow & 0.19 & 1.85 & 0.15 & 1.56 \\
\hline & Total area & 10.25 & & 10.25 & \\
\hline
\end{tabular}

Table 3: Error matrix and accuracy of visual (Google Earth Pro) and digital (Landsat 8, 2014) interpretation for the land use land cover (LULC) classes of the study landscape (Chopta-Tungnath)

\begin{tabular}{|c|c|c|c|c|c|}
\hline \multirow[t]{2}{*}{ SNo. } & \multirow[t]{2}{*}{ LULC classes } & \multicolumn{2}{|c|}{$\begin{array}{l}\text { Digital Interpretation } \\
\text { (Landsat 8, 2014) }\end{array}$} & \multicolumn{2}{|l|}{$\begin{array}{l}\text { Visual interpretation } \\
\text { (Google Earth Pro) }\end{array}$} \\
\hline & & Producer accuracy & User accuracy & Producer accuracy & User accuracy \\
\hline 1. & Mixed conifer forest & 81.82 & 81.82 & 89.47 & 89.47 \\
\hline 2. & Temperate grassland & 87.50 & 93.33 & 100.00 & 90.91 \\
\hline 3. & Rhododendron sub-alpine forest & 100.00 & 100.00 & 100.00 & 100.00 \\
\hline 4. & Alpine grassland & 40.00 & 40.00 & 81.82 & 90.00 \\
\hline 5. & Snow & 100.00 & 92.86 & 100.00 & 100.00 \\
\hline & $\begin{array}{l}\text { Overall accuracy } \\
\text { Kappa coefficient }\end{array}$ & $\begin{array}{l}86.00 \\
0.8165\end{array}$ & & $\begin{array}{l}92.00 \\
0.8930\end{array}$ & \\
\hline
\end{tabular}


Page $8 / 18$ 
Table 4: Lichens and their quantitative diversity (quadrate frequency) recorded in the four sites of the three RS- GIS recognised LULC types of the Chopta-Tungnath landscape

\begin{tabular}{|c|c|c|c|c|c|c|c|c|c|c|c|c|c|c|c|c|}
\hline \multirow[t]{2}{*}{ SNo. } & \multirow[t]{2}{*}{ Lichen Species } & \multirow[t]{2}{*}{ Family } & \multirow{2}{*}{$\begin{array}{l}\text { Growth } \\
\text { form }\end{array}$} & \multirow{2}{*}{$\begin{array}{l}\text { Elevation } \\
\text { (m) }\end{array}$} & \multicolumn{3}{|c|}{ Site 1} & \multicolumn{3}{|c|}{ Site 2} & \multicolumn{3}{|c|}{ Site 3} & \multicolumn{3}{|c|}{ Site 4} \\
\hline & & & & & $\mathrm{Cr}$ & Sx & $\operatorname{Tr}$ & $\mathrm{Cr}$ & Sx & $\operatorname{Tr}$ & $\mathrm{Cr}$ & Sx & $\operatorname{Tr}$ & $\mathrm{Cr}$ & Sx & $\operatorname{Tr}$ \\
\hline 1. & Bryoria confusa & Parmeliaceae & Fo & 3321 & - & - & - & 6.7 & - & 26.7 & - & - & - & - & - & - \\
\hline 2. & $\begin{array}{l}\text { Bulbothrix } \\
\text { setschwanensis }\end{array}$ & Parmeliaceae & Fo & 2967 & 33.3 & - & - & - & - & - & - & - & - & - & - & - \\
\hline 3. & $\begin{array}{l}\text { Cetrelia } \\
\text { olivetorum }\end{array}$ & Parmeliaceae & Fo & 2995 & - & - & 33.3 & - & - & - & - & - & - & - & - & - \\
\hline 4. & $\begin{array}{l}\text { Cetreliopsis } \\
\text { rhytidocarpa }\end{array}$ & Parmeliaceae & Fo & 2992 & 33.3 & - & - & - & - & - & - & - & - & - & - & - \\
\hline 5. & $\begin{array}{l}\text { Cladonia } \\
\text { cartilaginea }\end{array}$ & Cladoniaceae & $\mathrm{Cd}$ & 3384 & - & - & - & - & - & - & - & - & 33.3 & - & - & - \\
\hline 6. & $\begin{array}{l}\text { Cladonia } \\
\text { ceratophyllina }\end{array}$ & Cladoniaceae & $\mathrm{Cd}$ & 3558 & - & - & - & - & - & - & - & - & 33.3 & - & - & - \\
\hline 7. & $\begin{array}{l}\text { Cladonia } \\
\text { chlorophaea }\end{array}$ & Cladoniaceae & $\mathrm{Cd}$ & 3226 & - & - & - & - & - & - & - & - & 33.3 & - & - & - \\
\hline 8. & Cladonia coccifera & Cladoniaceae & $\mathrm{Cd}$ & 3225 & - & - & - & - & - & - & - & 6.7 & 26.7 & - & - & - \\
\hline 9. & Cladonia coccifera & Cladoniaceae & $\mathrm{Cd}$ & 3446 & - & - & - & - & - & - & - & - & - & - & - & 86.7 \\
\hline 10. & $\begin{array}{l}\text { Cladonia } \\
\text { coniocraea }\end{array}$ & Cladoniaceae & $\mathrm{Cd}$ & 2970 & 6.7 & - & 66.7 & - & - & - & - & - & - & - & - & - \\
\hline 11. & Cladonia fimbriata & Cladoniaceae & $\mathrm{Cd}$ & 3356 & - & - & - & - & - & - & - & - & 33.3 & - & - & - \\
\hline 12. & Cladonia furcata & Cladoniaceae & $\mathrm{Cd}$ & 3248 & - & - & - & - & - & - & - & - & 33.3 & - & - & - \\
\hline 13. & Cladonia pyxidata & Cladoniaceae & $\mathrm{Cd}$ & 3356 & - & - & - & - & - & - & - & - & - & - & - & 33.3 \\
\hline 14. & Cladonia ramulosa & Cladoniaceae & $\mathrm{Cd}$ & 2991 & - & - & 80 & - & - & - & - & - & - & - & - & - \\
\hline 15. & $\begin{array}{l}\text { Cladonia } \\
\text { scabriuscula }\end{array}$ & Cladoniaceae & $\mathrm{Cd}$ & 3130 & - & - & 66.7 & - & - & - & - & - & - & - & - & - \\
\hline 16. & Cladonia subulata & Cladoniaceae & $\mathrm{Cd}$ & 2943 & - & - & 66.7 & - & - & - & - & - & - & - & - & - \\
\hline 17. & $\begin{array}{l}\text { Dermatocarpon } \\
\text { miniatum }\end{array}$ & Verrucariaceae & Fo & 3131 & - & 46.7 & - & - & - & - & - & - & - & - & - & - \\
\hline 18. & $\begin{array}{l}\text { Dermatocarpon } \\
\text { vellereum }\end{array}$ & Verrucariaceae & Fo & $35-4$ & - & - & - & - & - & - & - & - & - & - & 33.3 & - \\
\hline 19. & $\begin{array}{l}\text { Everniastrum } \\
\text { cirrhatum }\end{array}$ & Parmeliaceae & Fo & 2966 & 80 & - & - & - & - & - & - & - & - & - & - & - \\
\hline 20. & $\begin{array}{l}\text { Everniastrum } \\
\text { nepalense }\end{array}$ & Parmeliaceae & Fo & 2942 & 73.3 & - & - & - & - & - & - & - & - & - & - & - \\
\hline 21. & $\begin{array}{l}\text { Flavopunctelia } \\
\text { soredica }\end{array}$ & Parmeliaceae & Fo & 2967 & 40 & - & - & - & - & - & - & - & - & - & - & - \\
\hline 23. & $\begin{array}{l}\text { Heterodermia } \\
\text { angustiloba }\end{array}$ & Physciaceae & Fo & 3272 & - & - & - & 33.3 & - & - & - & - & - & - & - & - \\
\hline 24. & $\begin{array}{l}\text { Heterodermia } \\
\text { boryi }\end{array}$ & Physciaceae & Fo & 2953 & 46.7 & - & - & - & - & - & - & - & - & - & - & - \\
\hline 25. & $\begin{array}{l}\text { Heterodermia } \\
\text { comosa }\end{array}$ & Physciaceae & Fo & 2946 & 13.3 & - & - & - & - & - & - & - & - & - & - & - \\
\hline 26. & $\begin{array}{l}\text { Heterodermia } \\
\text { diademata }\end{array}$ & Physciaceae & Fo & 2971 & 40 & 46.7 & - & - & - & - & - & - & - & - & - & - \\
\hline 27. & $\begin{array}{l}\text { Heterodermia } \\
\text { dissecta var. } \\
\text { koyana }\end{array}$ & Physciaceae & Fo & 2979 & 26.7 & 13.3 & - & - & - & - & - & - & - & - & - & - \\
\hline 28. & $\begin{array}{l}\text { Heterodermia } \\
\text { hypocaesia }\end{array}$ & Physciaceae & Fo & 3250 & - & - & - & 13.3 & - & 20 & - & - & - & - & - & - \\
\hline 29. & $\begin{array}{l}\text { Heterodermia } \\
\text { incana }\end{array}$ & Physciaceae & Fo & 2989 & 33.3 & - & - & - & - & - & - & - & - & - & - & - \\
\hline 30. & $\begin{array}{l}\text { Heterodermia } \\
\text { obscurata }\end{array}$ & Physciaceae & Fo & 3652 & - & - & - & - & - & - & - & - & - & - & - & 26.7 \\
\hline 31. & $\begin{array}{l}\text { Heterodermia } \\
\text { pseudospeciosa }\end{array}$ & Physciaceae & Fo & 2998 & - & 33.3 & - & - & - & - & - & - & - & - & - & - \\
\hline 32. & $\begin{array}{l}\text { Heterodermia } \\
\text { pseudospeciosa }\end{array}$ & Physciaceae & Fo & 3209 & - & - & - & - & 33.3 & 6.7 & - & - & - & - & - & - \\
\hline 33. & $\begin{array}{l}\text { Heterodermia } \\
\text { punctifera }\end{array}$ & Physciaceae & Fo & 3343 & - & - & - & 6.7 & 26.7 & - & - & - & - & - & - & - \\
\hline 34. & $\begin{array}{l}\text { Hypotrachyna } \\
\text { adducta }\end{array}$ & Parmeliaceae & Fo & 2930 & 6.7 & - & - & - & - & - & - & - & - & - & - & - \\
\hline 35. & $\begin{array}{l}\text { Hypotrachyna } \\
\text { awasthii }\end{array}$ & Parmeliaceae & Fo & 3253 & - & - & - & 33.3 & - & - & - & - & - & - & - & - \\
\hline 36. & $\begin{array}{l}\text { Hypotrachyna } \\
\text { crenata }\end{array}$ & Parmeliaceae & Fo & 2994 & 26.7 & 3.3 & 3.3 & - & - & - & - & - & - & - & - & - \\
\hline 37. & Hypotrachyna & Parmeliaceae & Fo & 2925 & 13.3 & - & - & - & - & - & - & - & - & - & - & - \\
\hline
\end{tabular}


physcioides

\begin{tabular}{|c|c|c|c|c|c|c|c|c|c|c|c|c|c|c|c|}
\hline $\begin{array}{l}\text { 38. Hypotrachyna } \\
\text { pindarensis }\end{array}$ & Parmeliaceae & Fo & 3456 & - & - & - & - & - & - & - & - & - & - & 33.3 & - \\
\hline $\begin{array}{l}\text { 39. } \begin{array}{l}\text { Hypotrachyna } \\
\text { pseudo-sinuosa }\end{array}\end{array}$ & Parmeliaceae & Fo & 3548 & - & - & - & - & - & - & - & - & - & 33.3 & - & - \\
\hline $\begin{array}{l}\text { Lepraria } \\
\text { caesioalba var. } \\
\text { groenlandica }\end{array}$ & Stereocaulaceae & $\mathrm{Lp}$ & 2991 & - & - & 33.3 & - & - & - & - & - & - & - & - & - \\
\hline Lepraria neglecta & Stereocaulaceae & Lp & 2926 & 6.7 & 6.7 & 40 & - & - & - & - & - & - & - & - & - \\
\hline $\begin{array}{l}\text { Leptogium } \\
\text { askotense }\end{array}$ & Collemataceae & Fo & 3442 & - & - & - & - & - & - & 6.7 & 6.7 & 20 & - & - & - \\
\hline $\begin{array}{l}\text { Leptogium } \\
\text { burnetiae }\end{array}$ & Collemataceae & Fo & 3237 & - & - & - & 26.7 & 13.3 & - & - & - & - & - & - & - \\
\hline Leptogium delavayi & Collemataceae & Fo & 3546 & - & - & - & - & - & - & - & - & - & 6.7 & - & 33.3 \\
\hline $\begin{array}{l}\text { Leptogium } \\
\text { javanicum }\end{array}$ & Collemataceae & Fo & 3358 & - & - & - & - & - & - & 13.3 & - & 20 & - & - & - \\
\hline $\begin{array}{l}\text { Leptogium } \\
\text { pedicellatum }\end{array}$ & Collemataceae & Fo & 2987 & 33.3 & - & 66.7 & - & - & - & - & - & - & - & - & - \\
\hline $\begin{array}{l}\text { Leptogium } \\
\text { trichophorum }\end{array}$ & Collemataceae & Fo & 3254 & - & - & - & 13.3 & - & 20 & - & - & - & - & - & - \\
\hline Lobaria isidiosa & Lobariaceae & Fo & 2996 & 33.3 & - & - & - & - & - & - & - & - & - & - & - \\
\hline $\begin{array}{l}\text { Lobaria } \\
\text { kurokawae }\end{array}$ & Lobariaceae & Fo & 2991 & - & - & 33.3 & - & - & - & - & - & - & - & - & - \\
\hline Lobaria retigera & Lobariaceae & Fo & 3248 & - & - & - & - & - & - & - & 6.7 & 26.7 & - & - & - \\
\hline Melanelia stygia & Parmeliaceae & Fo & 3400 & - & - & - & - & - & - & - & - & - & - & 20 & 13.3 \\
\hline $\begin{array}{l}\text { Myelochroa } \\
\text { entotheiochroa }\end{array}$ & Parmeliaceae & Fo & 2994 & 33.3 & - & - & - & - & - & - & - & - & - & - & - \\
\hline $\begin{array}{l}\text { Myelochroa } \\
\text { perisidians }\end{array}$ & Parmeliaceae & Fo & 2994 & 33.3 & - & - & - & - & - & - & - & - & - & - & - \\
\hline $\begin{array}{l}\text { Nephroma } \\
\text { helveticum }\end{array}$ & Nephromataceae & Fo & 2947 & 26.7 & - & - & - & - & - & - & - & - & - & - & - \\
\hline $\begin{array}{l}\text { Parmelia } \\
\text { meiophora }\end{array}$ & Parmeliaceae & Fo & 3227 & - & - & - & 33.3 & - & - & - & - & - & - & - & - \\
\hline Parmelia saxatilis & Parmeliaceae & Fo & 3307 & - & - & - & 13.3 & 20 & - & - & - & - & - & - & - \\
\hline Parmelia sulcata & Parmeliaceae & Fo & 3228 & - & - & - & 33.3 & - & - & - & - & - & - & - & - \\
\hline $\begin{array}{l}\text { Parmelinella } \\
\text { simplicior }\end{array}$ & Parmeliaceae & Fo & 2979 & 46.7 & - & - & - & - & - & - & - & - & - & - & - \\
\hline $\begin{array}{l}\text { Parmelinella } \\
\text { wallichiana }\end{array}$ & Parmeliaceae & Fo & 2942 & 46.7 & - & - & - & - & - & - & - & - & - & - & - \\
\hline $\begin{array}{l}\text { Parmotrema } \\
\text { andinum }\end{array}$ & Parmeliaceae & Fo & 2938 & 6.7 & 26.7 & - & - & - & - & - & - & - & - & - & - \\
\hline $\begin{array}{l}\text { Parmotrema } \\
\text { nilgherrense }\end{array}$ & Parmeliaceae & Fo & 2993 & 26.7 & - & - & - & - & - & - & - & - & - & - & - \\
\hline $\begin{array}{l}\text { Parmotrema } \\
\text { reticulatum }\end{array}$ & Parmeliaceae & Fo & 2952 & 53.3 & - & - & - & - & - & - & - & - & - & - & - \\
\hline $\begin{array}{l}\text { Parmotrema } \\
\text { robustum }\end{array}$ & Parmeliaceae & Fo & 3139 & - & - & - & 33.3 & - & - & - & - & - & - & - & - \\
\hline $\begin{array}{l}\text { Parmotrema } \\
\text { saccatilobum }\end{array}$ & Parmeliaceae & Fo & 2991 & 33.3 & - & - & - & - & - & - & - & - & - & - & - \\
\hline $\begin{array}{l}\text { Parmotrema } \\
\text { tinctorum }\end{array}$ & Parmeliaceae & Fo & 2959 & - & 33.3 & - & - & - & - & - & - & - & - & - & - \\
\hline Peltigera canina & Peltigeraceae & Fo & 3445 & - & - & - & - & - & - & - & - & 33.3 & - & - & - \\
\hline $\begin{array}{l}\text { Peltigera } \\
\text { dolichorrhiza }\end{array}$ & Peltigeraceae & Fo & 3456 & - & - & - & - & - & - & 6.7 & 6.7 & 20 & - & - & - \\
\hline $\begin{array}{l}\text { Peltigera } \\
\text { praetextata }\end{array}$ & Peltigeraceae & Fo & 3444 & - & - & - & - & - & - & - & - & 33.3 & - & - & - \\
\hline $\begin{array}{l}\text { Peltigera } \\
\text { rufescens }\end{array}$ & Peltigeraceae & Fo & 3205 & - & - & - & - & - & - & - & - & 33.3 & - & - & - \\
\hline $\begin{array}{l}\text { Phaeophyscia } \\
\text { endococcina }\end{array}$ & Physciaceae & Fo & 2944 & 40 & - & - & - & - & - & - & - & - & - & - & - \\
\hline $\begin{array}{l}\text { Phaeophyscia } \\
\text { hispidula }\end{array}$ & Physciaceae & Fo & 2988 & 53.3 & - & - & - & - & - & - & - & - & - & - & - \\
\hline Physconia grisea & Physciaceae & Fo & 3652 & - & - & - & - & - & - & - & - & - & - & - & 33.3 \\
\hline Punctelia rudecta & Parmeliaceae & Fo & 3303 & - & - & - & 33.3 & - & - & - & - & - & - & - & - \\
\hline $\begin{array}{l}\text { Ramalina } \\
\text { himalayensis }\end{array}$ & Ramalinaceae & Fr & 3402 & - & - & - & - & - & - & 26.7 & 6.7 & - & - & - & - \\
\hline Ramalina hossei & Ramalinaceae & Fr & 2938 & 33.3 & - & 13.3 & - & - & - & - & - & - & - & - & - \\
\hline Ramalina roesleri & Ramalinaceae & Fr & 2944 & 20 & - & - & - & - & - & - & - & - & - & - & - \\
\hline
\end{tabular}




\begin{tabular}{|c|c|c|c|c|c|c|c|c|c|c|c|c|c|c|c|c|}
\hline 78. & Ramalina sinensis & Ramalinaceae & Fr & 2950 & 33.3 & - & - & - & - & - & - & - & - & - & - & - \\
\hline 79. & $\begin{array}{l}\text { Stereocaulon } \\
\text { alpinum }\end{array}$ & Stereocaulaceae & $\mathrm{Cd}$ & 3344 & - & - & - & - & 6.7 & 26.7 & - & - & - & - & - & - \\
\hline 80. & $\begin{array}{l}\text { Stereocaulon } \\
\text { foliolosum }\end{array}$ & Stereocaulaceae & $\mathrm{Cd}$ & 3350 & - & - & - & - & 6.7 & 26.7 & - & - & - & - & - & - \\
\hline 81. & $\begin{array}{l}\text { Stereocaulon } \\
\text { foliolosum var } \\
\text { strictum }\end{array}$ & Stereocaulaceae & $\mathrm{Cd}$ & 3253 & - & - & - & - & 6.7 & 26.7 & - & - & - & - & - & - \\
\hline 82. & $\begin{array}{l}\text { Stereocaulon } \\
\text { macrocephalum }\end{array}$ & Stereocaulaceae & $\mathrm{Cd}$ & 3486 & - & - & - & - & - & - & - & - & - & - & 6.7 & 26.7 \\
\hline 83. & $\begin{array}{l}\text { Stereocaulon } \\
\text { massartianum }\end{array}$ & Stereocaulaceae & $\mathrm{Cd}$ & 2957 & - & - & 33.3 & - & - & - & - & - & - & - & - & - \\
\hline 84. & $\begin{array}{l}\text { Stereocaulon } \\
\text { pomiferum }\end{array}$ & Stereocaulaceae & $\mathrm{Cd}$ & 2936 & - & - & 66.7 & - & - & - & - & - & - & - & - & - \\
\hline 85. & Sticta henryana & Lobariaceae & Fo & 2944 & 6.7 & - & - & - & - & - & - & - & - & - & - & - \\
\hline 86. & $\begin{array}{l}\text { Umbilicaria } \\
\text { indica var. nana }\end{array}$ & Umbilicariaceae & Fo & 3252 & - & - & - & - & 33.3 & - & - & - & - & - & - & - \\
\hline 87. & Umbilicaria vellea & Umbilicariaceae & Fo & 3645 & - & - & - & - & - & - & - & - & - & - & 33.3 & - \\
\hline 88. & Usnea baileyi & Parmeliaceae & $\mathrm{Fr}$ & 3391 & - & - & - & 33.3 & - & - & - & - & - & - & - & - \\
\hline 89. & Usnea himalayana & Parmeliaceae & Fr & 3179 & - & - & - & 33.3 & - & - & - & - & - & - & - & - \\
\hline 90. & Usnea longissima & Parmeliaceae & Fr & 3542 & - & - & - & - & - & - & - & - & - & - & - & 33.3 \\
\hline 99. & Usnea orientalis & Parmeliaceae & $\mathrm{Fr}$ & 2927 & 33.3 & - & - & - & - & - & - & - & - & - & - & - \\
\hline 100. & Usnea perplexans & Parmeliaceae & Fr & 2949 & 73.3 & - & - & - & - & - & - & - & - & - & - & - \\
\hline 101. & $\begin{array}{l}\text { Usnea } \\
\text { pseudosinensis }\end{array}$ & Parmeliaceae & Fr & 2971 & 33.3 & - & - & - & - & - & - & - & - & - & - & - \\
\hline 102. & $\begin{array}{l}\text { Usnea } \\
\text { stigmatoides }\end{array}$ & Parmeliaceae & Fr & 2949 & 13.3 & - & - & - & - & - & - & - & - & - & - & - \\
\hline 103. & Usnea subfloridana & Parmeliaceae & Fr & 2927 & 6.7 & - & - & - & - & - & - & - & - & - & - & - \\
\hline 104. & Usnea eumitrioides & Parmeliaceae & $\mathrm{Fr}$ & 2903 & 33.3 & - & - & - & - & - & - & - & - & - & - & - \\
\hline
\end{tabular}

Growth forms, Lp leprose, Fo foliose, Fr fruticose, Cd compound; Substrate subsets, Cr corticolous (on bark), Sx saxicolous (on rock), Tr terricolous (on soil)

\section{Figures}
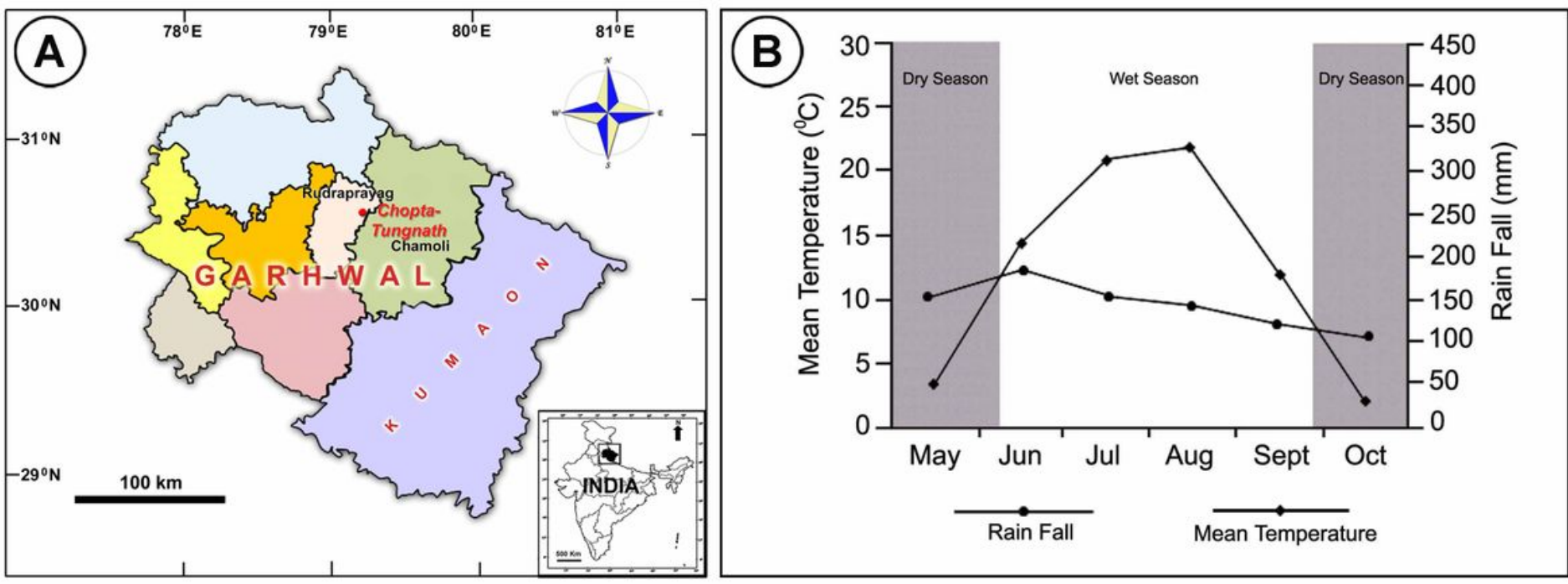

Figure 1

A, the location map of the study area, B, the pluviothermic diagram showing wet and dry months in Chopta- Tungnath landscape (redrawn after Rai et al. 2012a) 


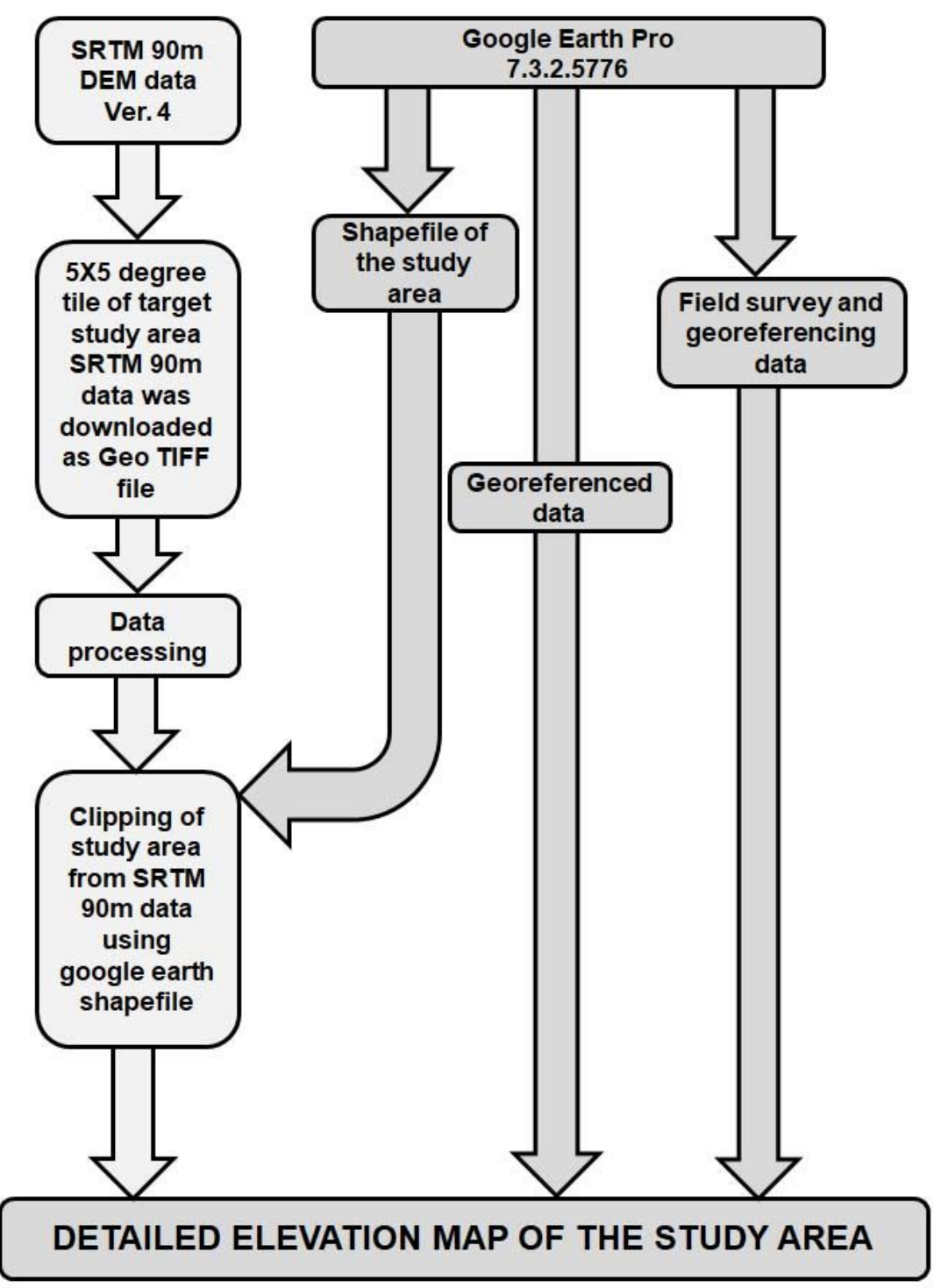

Figure 2

An overview of SRTM-DEM analysis. 


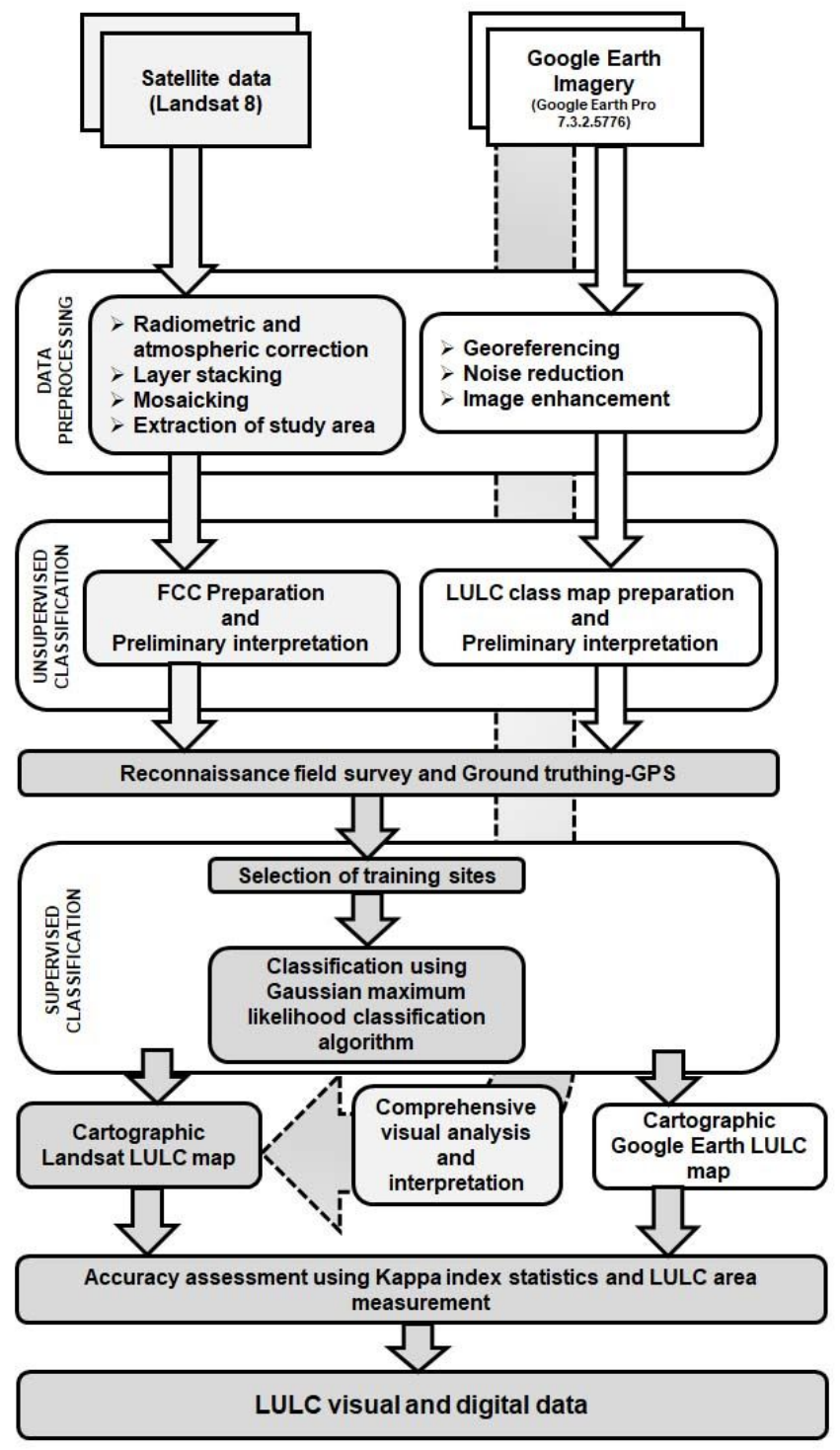

Figure 3

An overview of RS-GIS based land use land cover (LULC) analysis. 


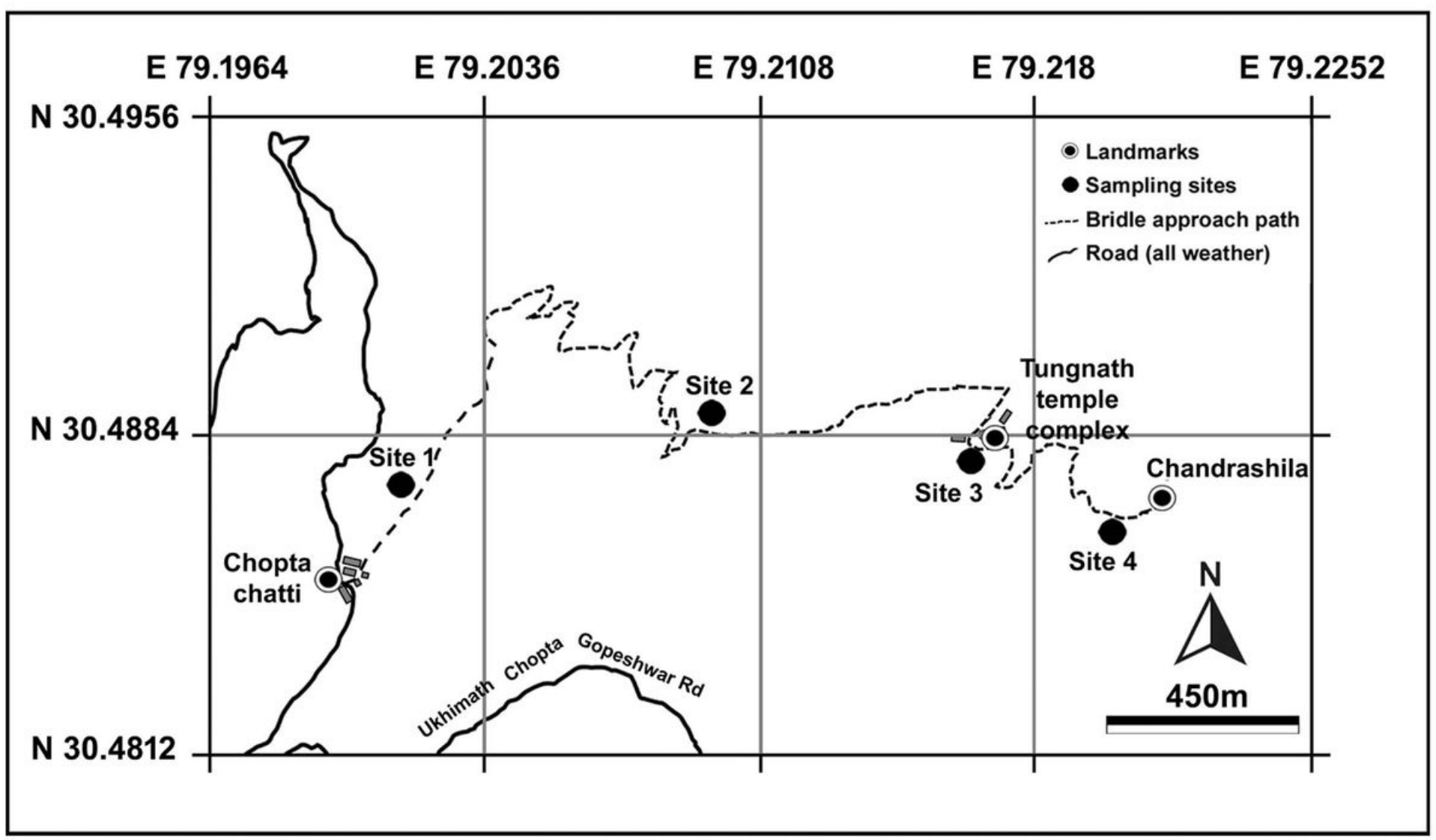

Figure 4

The detailed map of study area depicting all the sampling sites and landmarks in Chopta-Tungnath landscape. 

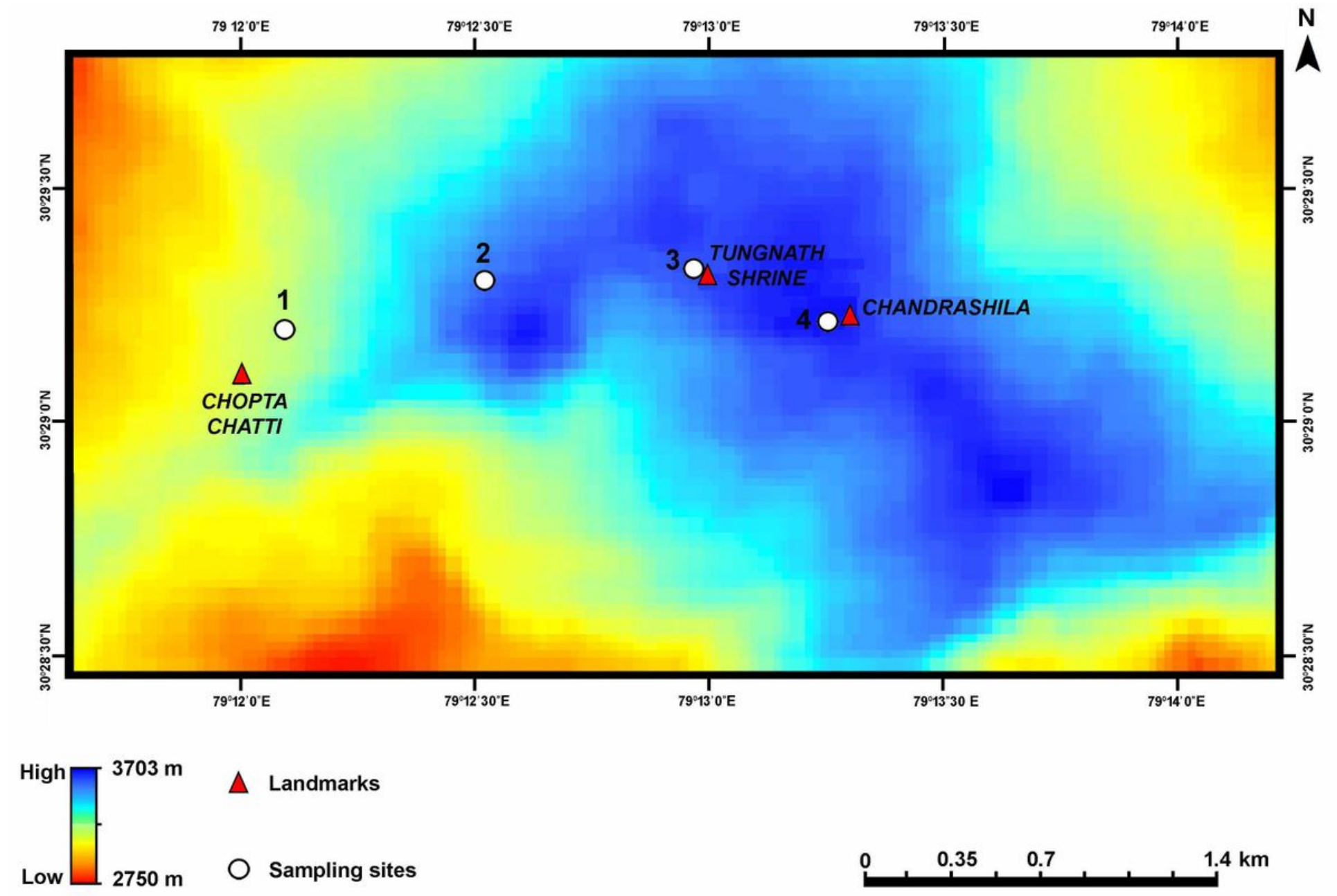

Figure 5

The SRTM-DEM visualized map with sampling sites and major landmarks tagged. 

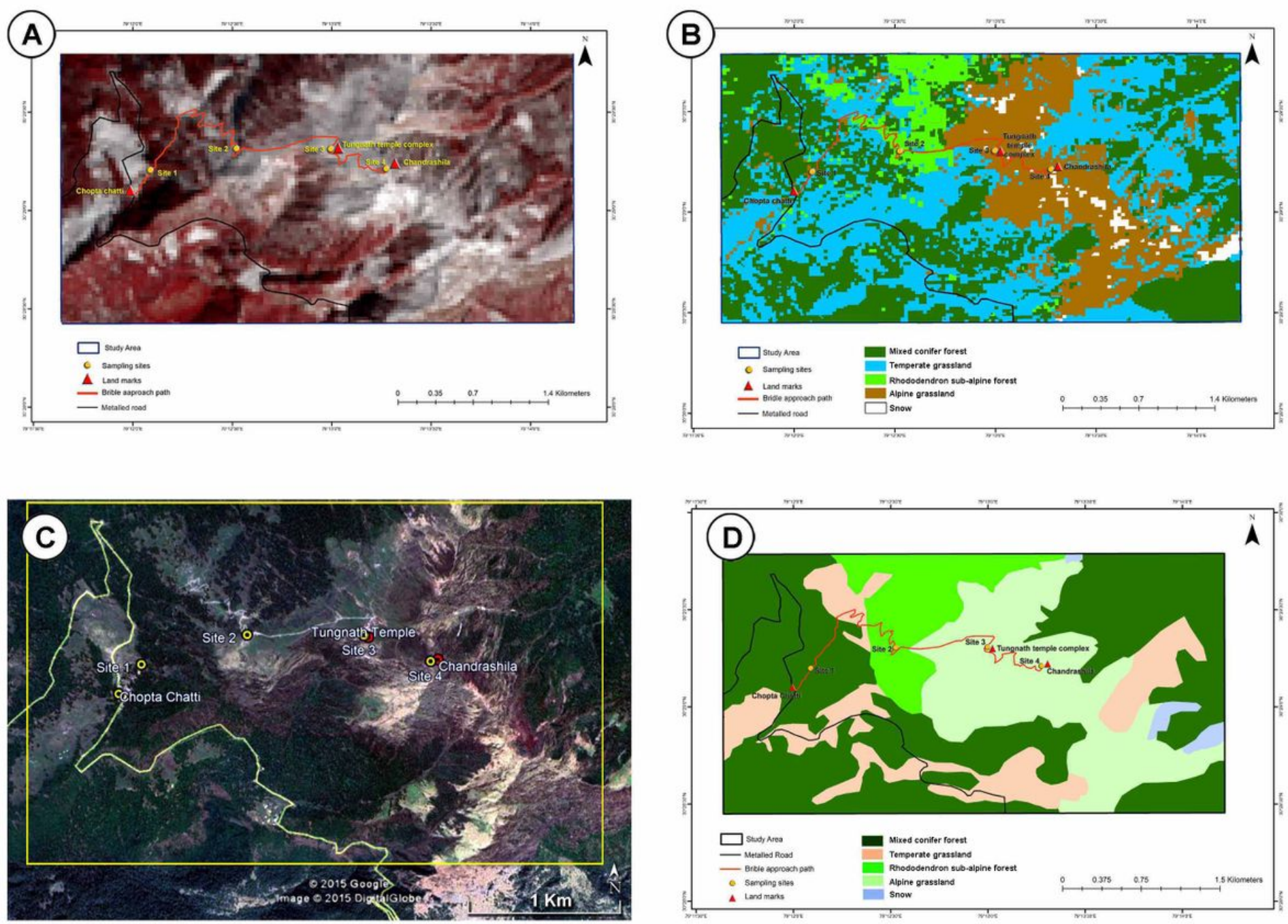

\section{Figure 6}

The RS-GIS based land use land cover (LULC) classification of the Chopta-Tungnath landscape-A, The Landsat 8, 2014 false-colour composite map of Chopta-Tungnath landscape; B, The digital supervised LULC classes of Landsat 8 data; C, The Google earth pro map of the study area; D, The visual classified LULC classes of Google earth pro map data. 

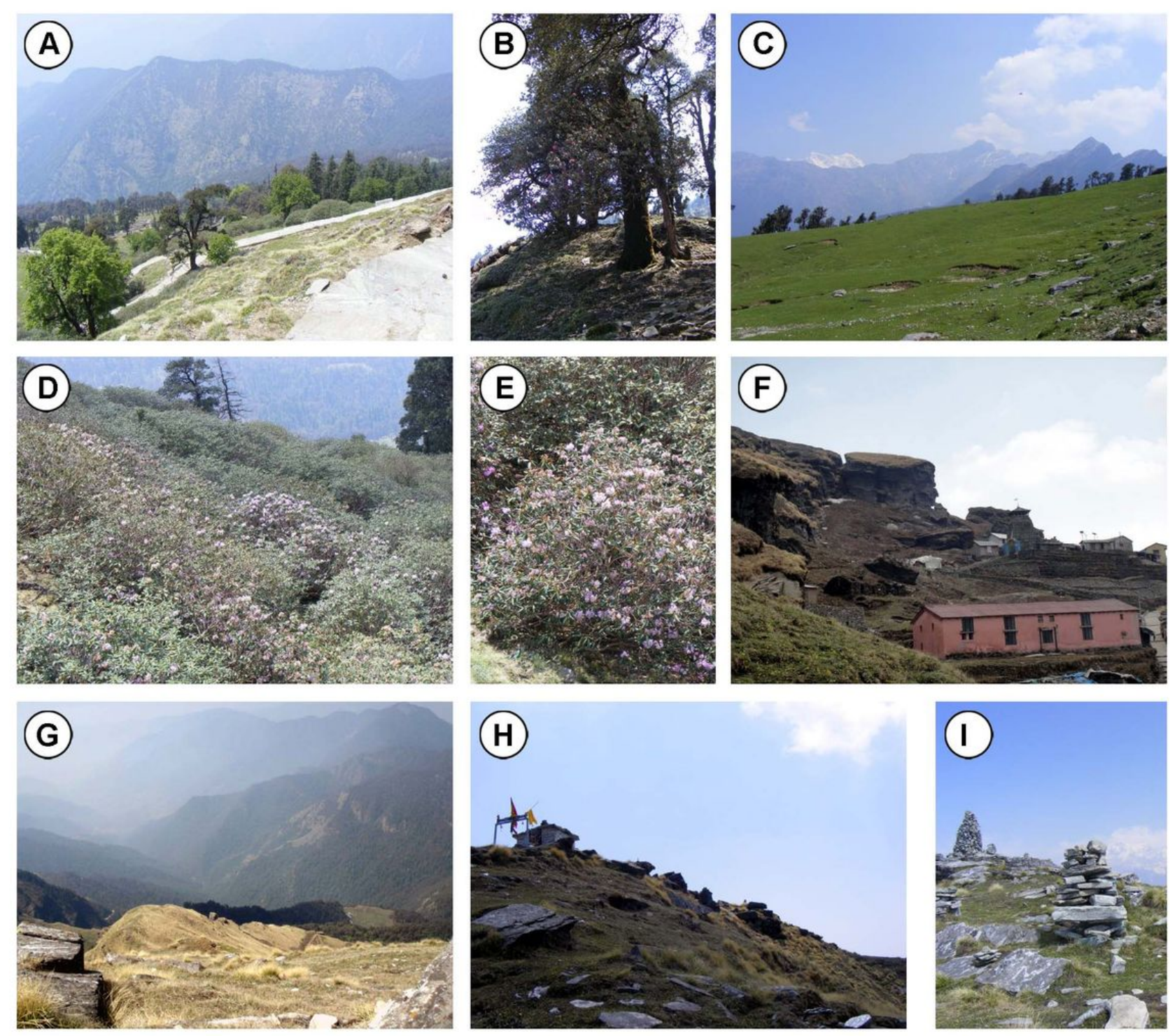

\section{Figure 7}

The environs of Chopta-Tungnath landscape-A. The mixed conifer forests; B. Rhododendron arboreum strand in mixed conifer forest; C, The temperate grasslands; D, The Rhododendron sub-alpine forest; E, Rhododendron campanulatum stand in Rhododendron sub-alpine forest; F, The Tungnath shrine; G, The alpine grassland; $\mathrm{H}$, The Chandrashila; I, The cairns at Chandrashila.

(A)

\section{Site 4}

Site 3

Site 2

Site 1

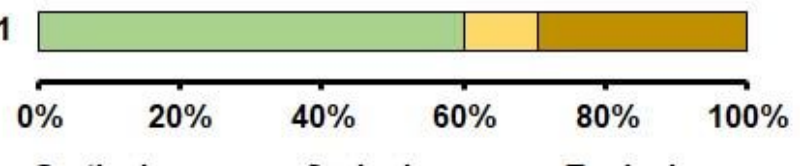

$\square$ Corticolous
(B)

Site 4

Site 3

Site 2

Site

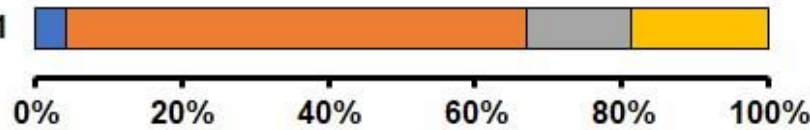

$\square$ Leprose $\square$ Foliose $\square$ Fruticose $\square$ Compound

Figure 8 
The site-wise variation of A, lichen habitat-subsets; B, lichen growth forms in the Chopta-Tungnath landscape.

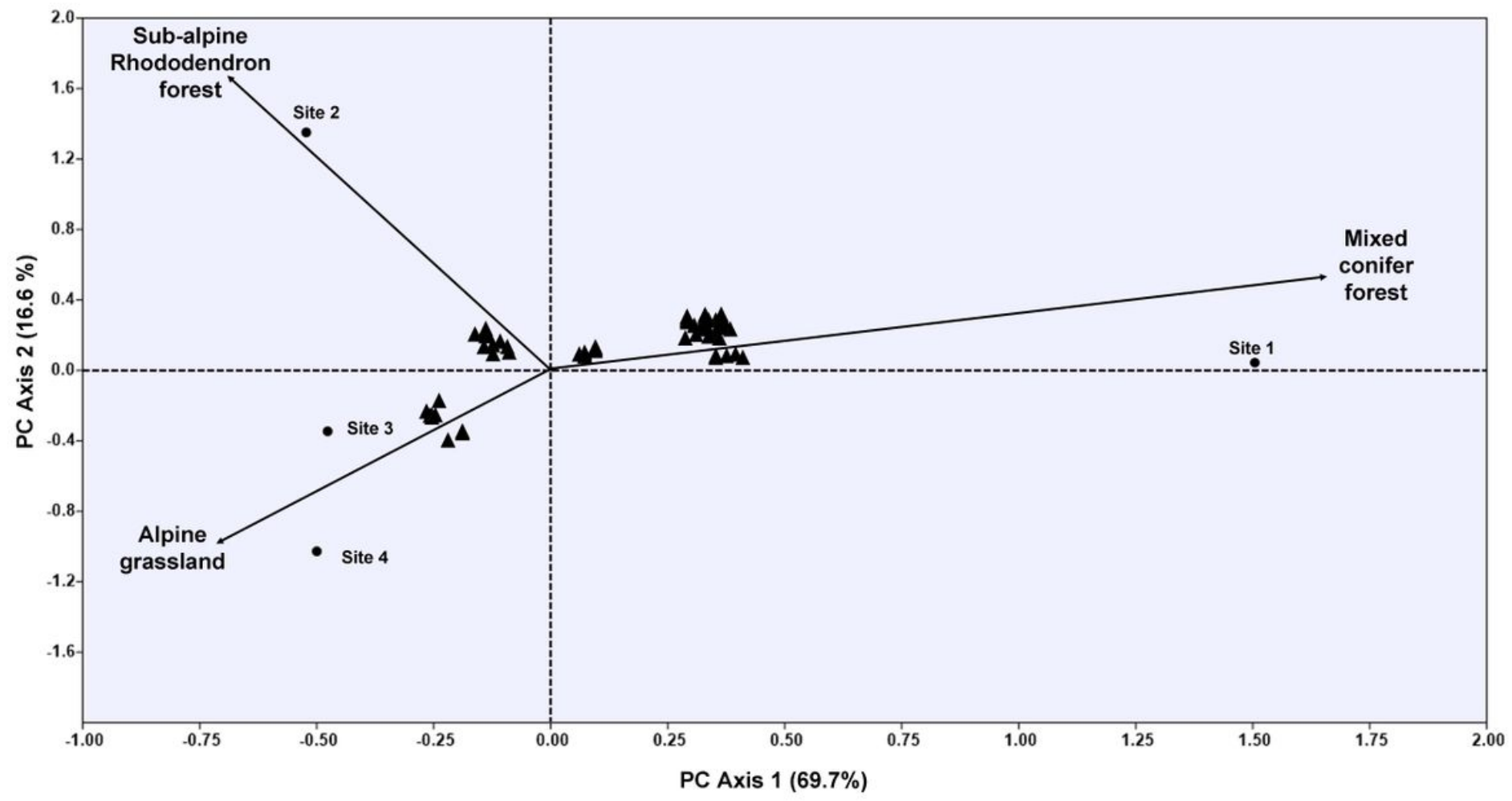

\section{Figure 9}

PCA ordination bi-plot of the four lichen study site data along the three RS-GIS recognized LULC classes in the Chopta-Tungnath landscape. 